\title{
TSKS wt Allele
}

National Cancer Institute

\section{Source}

National Cancer Institute. TSKS wt Allele. NCI Thesaurus. Code C54543.

Human TSKS wild type allele is located in the vicinity of $19 q 13.3$ and is approximately 24

$\mathrm{kb}$ in length. This allele, which encodes testis-specific serine kinase substrate protein, may play a role in testicular physiology. 